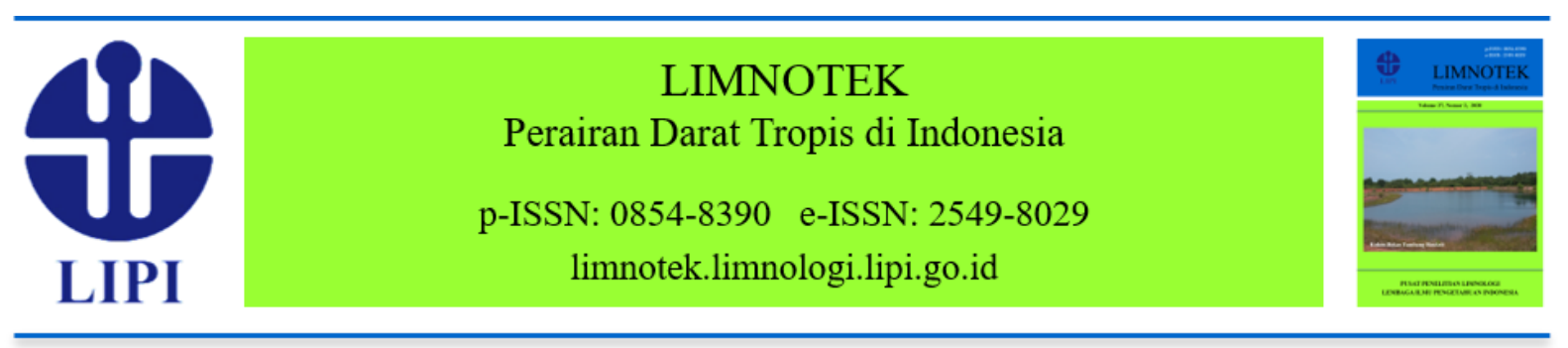

\title{
Kinerja Pertumbuhan dan Kelangsungan Hidup Ikan Patin Pasupati (Pangasius sp.) pada Kecepatan Arus Berbeda
}

\author{
Djamhuriyah Syaikh Said, Nina Hermayani Sadi, Novi Mayasari, \\ Agus Waluyo, Eva Nafisyah
}

Pusat Penelitian Limnologi, Lembaga Ilmu Pengetahuan Indonesia (LIPI)

Email: djamhuriyah@limnologi.lipi.go.id

Diajukan 15 November 2019. Ditelaah 11 Juni 2020. Disetujui 10 Desember 2020.

\begin{abstract}
Abstrak
Ikan Patin (Pangasius sp.) hidup secara alami di sungai dan memiliki ciri berkulit halus. Pemeliharaan ikan Patin dengan padat tebar yang cukup tinggi membutuhkan sistem pemeliharaan khusus, seperti sistem berarus. Penelitian ini mempelajari pengaruh arus terhadap kinerja pertumbuhan dan kelangsungan hidup ikan Patin Pasupati yang merupakan hasil persilangan antara ikan Patin Siam dengan ikan Patin Jambal. Penelitian dilakukan selama 93 hari (November 2018-Februari 2019) di Laboratorium Akuatik, Pusat Penelitian Limnologi LIPI menggunakan bak fiberglas persegi panjang bervolume 875 L yang dilengkapi dengan sistem resirkulasi. Variasi kecepatan arus yang digunakan yaitu A $(0 \mathrm{~m} / \mathrm{s}), \mathrm{B}(0,2 \mathrm{~m} / \mathrm{s})$, dan C $(0,4 \mathrm{~m} / \mathrm{s})$. Ikan Patin yang diteliti berukuran panjang dan berat awal 13,64 $\pm 1,26(12-14) \mathrm{cm}$ dan 24,41 $\pm 3,87$ (22,07-29.19) g dengan kepadatan awal 40 ekor/bak. Analisis data yang dilakukan secara deskriptif memperlihatkan bahwa perlakuan $\mathrm{C}$ memberikan hasil tertinggi pada $90 \%$ parameter pertumbuhan ikan yang diamati, yaitu panjang akhir $31,17 \pm 0,78 \mathrm{~cm}$, berat akhir $295,72 \pm 43,02 \mathrm{~g}$, pertambahan panjang $17,53 \pm 0,78 \mathrm{~cm}$, pertambahan berat 271,31 $\pm 43,02 \mathrm{~g}$, pertumbuhan spesifik (SGR) panjang 0,89 $\pm 0,03 \%$ dan SGR berat 2,68 $\pm 0,15 \%$, pertumbuhan panjang $0,19 \pm 0,01 \mathrm{~cm} / \mathrm{hari}$, pertumbuhan berat 2,92 $\pm 0.46 \mathrm{~g} / \mathrm{hari}$, dan kelangsungan hidup (SR) 87,98 $\pm 10,84 \%$. Namun, nilai rasio konversi pakan (FCR) ketiga perlakuan relatif sama. Kecepatan arus tidak berpengaruh pada nilai FCR dan peningkatan arus tidak diiringi dengan peningkatan jumlah pakan. Penelitian ini belum mendapatkan kecepatan arus optimal untuk pertumbuhan dan kelangsungan hidup ikan Patin Pasupati. Oleh karena itu, penelitian lanjutan diperlukan untuk mengetahui kecepatan arus optimal yang akan menghasilkan pertumbuhan maksimal ikan Patin Pasupati.
\end{abstract}

Kata kunci: kecepatan arus, pertumbuhan, kelangsungan hidup, ikan Patin Pasupati 


\begin{abstract}
Growth Performance and Survival of Pangasius Pasupati (Pangasius sp.) at Different Flow Rates. Pangasius is a freshwater fish with a typical delicate skin. A research of water flow effects on growth performance and survival of Pangasius Pasupati has been conducted with three replications in the Laboratory of the Research Center for Limnology LIPI for 93 days (November 2018-February 2019). Pangasius Pasupati is the hybrid of Pangasianodon hypopthalmus and Pangasius djambal. The initial length and weight of fish samples were 13,64 $\pm 1,26(12-14) \mathrm{cm}$ and 24,41 $\pm 3,87$ (22.07-29.19) $\mathrm{g}$ respectively. Three flow rate treatments were tested, i.e. A ( $0 \mathrm{~m} / \mathrm{s}$ as a control), B $(0,2 \mathrm{~m} / \mathrm{s})$, and C $(0,4 \mathrm{~m} / \mathrm{s})$. An initial density of 40 fish were reared in a rectangular fiberglass basin filled with $875 \mathrm{~L}$ of water using a recirculation system. The data obtained were analyzed descriptively and showed that the treatment $\mathrm{C}$ gave the highest yield on $90 \%$ of the observed fish growth parameters, which were the final length $(31,17 \pm 0,78 \mathrm{~cm})$, weight size $(295,72 \pm 43,02 \mathrm{~g})$, length gain $(17,53 \pm$ $0,78 \mathrm{~cm})$, weight gain $(271,31 \pm 43,02 \mathrm{~g})$, specific growth rate of length $(0,89 \pm 0,03 \%)$, specific growth rate of weight $(2,68 \pm 0,15 \%)$, absolute daily growth of length $(0,19 \pm 0,01 \mathrm{~cm} /$ day $)$, absolute daily growth of weight $(2,92 \pm 0,46 \mathrm{~g} /$ day $)$, and survival rate $(87,98 \pm 10,84 \%)$. However, the feed conversion ratio (FCR) values of the three treatments were relatively the same. The flow rates had no effect on the FCR and an increase in the flow rate was not accompanied by an increase in the amount of feed. This study has not obtained the optimal water flow rate for the growth and survival of Pangasius Pasupati. Therefore, further research is necessary to determine the optimal flow rate that will produce maximum growth of the fish.
\end{abstract}

Keywords: water flow rate, growth, survival, Pangasius Pasupati

\section{Pendahuluan}

Ikan Patin Pasupati (Pangasius sp.) yang memiliki daging berwarna putih merupakan hasil persilangan antara induk ikan Patin Siam (Pangasianodon hypopthalmus) dan pejantan ikan Patin Jambal (Pangasius djambal). Ikan Patin Pasupati dirilis sebagai ikan budi daya unggul pada Agustus 2006 berdasarkan Keputusan Menteri Kelautan dan Perikanan Nomor KEP.25/MEN/2006 tentang Pelepasan Varietas Ikan Patin Pasupati sebagai Varietas Benih Unggul. Nama Pasupati merupakan singkatan dari kata Patin Super Harapan Pertiwi. Ikan Patin Jambal atau Pangasius djambal yang sebelumnya dikenal dengan nama Pangasius pangasius merupakan ikan asli Indonesia yang unggul dan hidup di sungaisungai besar di Sumatra, Jawa, dan Kalimantan (Nasa, 2014; Cholik et al., 2005; Kottelat et al., 1993). Ikan Patin Siam
(Pangasianodon hypophthalmus) merupakan ikan Patin asli Sungai Mekong (Vidthayanon \& Hogan, 2011; Foo, 2010). Induk ikan Patin Siam memiliki jumlah telur 10 kali lebih banyak daripada ikan Patin Jambal. Dengan demikian, hibrida yang dihasilkan memiliki keunggulan, yaitu daging yang putih mengikuti tetua jantan dan jumlah telur yang banyak mengikuti tetua betina (Jadmiko Darmawan, Peneliti Balai Riset Kelautan dan Perikanan, Sukamandi, komunikasi pribadi, Agustus 2018).

Secara alami, ikan Patin yang berkulit halus dan tidak bersisik, hidup di sungaisungai yang berarus lambat dan aktif pada malam hari (Kottelat et al., 1993). Kulit ikan Patin memiliki keunggulan karena mengandung kolagen. Suptijah et al. (2018) menyatakan bahwa salah satu bahan kulit ikan yang berpotensi sebagai sumber kolagen adalah kulit ikan Patin. Hardyanti (2014) mendapatkan kandungan kolagen 
yang cukup tinggi pada ikan Patin, yaitu sebesar $2,75 \mathrm{mg} / \mathrm{kg}$ kulit ikan atau setara dengan $85,3 \mathrm{mg} / \mathrm{kg}$ ikan. Huong et al. (2014) juga meneliti kandungan kolagen pada kulit ikan Patin Siam. Friess (1998) menyatakan bahwa lebih dari $50 \%$ protein ekstraseluler pada kulit ikan merupakan kolagen. Kolagen memegang peranan cukup penting dalam industri makanan, kosmetik, biomedis, dan farmasi (Chai et al., 2010). Merujuk pada informasi tersebut, maka perlu dicari sistem pemeliharaan yang tepat untuk memproduksi ikan Patin dalam jumlah banyak dengan pertumbuhan cepat. Karena secara alami ikan Patin hidup di sungai yang berarus, maka sistem pemeliharaan berarus diduga dapat memengaruhi pertumbuhan dan kelangsungan hidup ikan Patin.

Arus air berpengaruh pada kehidupan ikan, antara lain untuk pertumbuhannya. Wagner (2015) menyatakan bahwa laju aliran air dan variasinya memberikan efek yang bervariasi dan kompleks pada kehidupan perairan. Efek-efek ini dapat secara langsung memengaruhi kelangsungan hidup dan perilaku pada tiap fase kehidupan ikan, invertebrata, tumbuhan, atau hewan lain.

Beberapa penelitian penggunaan arus untuk pertumbuhan ikan telah dilakukan pada ikan Lele (Clarias fuscus), ikan Turbot (Scophthalmus maximus), ikan Salmon Atlantik (Salmo salar), dan juvenil ikan Salmon (Solstorms et al., 2015; Schram et al., 2009; Jobling et al., 1993; Diana \& Fast, 1989). Penelitian tentang ikan Patin telah banyak pula dilakukan antara lain tentang penyakit, faktor biologis calon induk, hubungan morfometrik dengan fekunditas, pertumbuhan pada sistem resirkulasi, kinerja pertumbuhan dan heritabilitas ikan Patin Jambal (Sularto et al., 2014, 2012, 2011; Andriyanto \& Listyanto, 2011; Ahmad et al., 2008; Supriyadi et al., 2003). Selain itu, Tahapari et al. (2017) juga telah meneliti daya adaptasi beberapa spesies ikan Patin. Penelitian ini bertujuan untuk mendapatkan kecepatan arus optimal untuk meningkatkan pertumbuhan dan kelang- sungan hidup ikan Patin Pasupati. Pertumbuhan yang cepat dan kelangsungan hidup yang tinggi akan berpengaruh pada peningkatan biomassa ikan Patin yang dihasilkan yang menjadi bahan dasar untuk mendapatkan lebih banyak kolagen.

\section{Bahan dan Metode}

\section{Penyiapan Ruangan}

Penelitian awal dilakukan mulai bulan Juli 2018 menggunakan bak, volume air, dan kecepatan arus tertentu. Bak-bak pemeliharaan diletakkan di dalam ruangan yang beratap, namun tidak berdinding. Bakbak diisi air PDAM, kemudian dioperasikan selama tujuh hari sebelum diisi ikan sampel. Sistem pemeliharaan ini diterapkan selama empat periode aklimatisasi dan menunjukkan kematian ikan yang banyak dalam waktu 2-8 hari. Hal ini diduga berhubungan dengan fluktuasi suhu dan kondisi air pemeliharaan. Untuk mengatasi hal tersebut, maka penelitian menggunakan bak yang sama dilaksanakan di dalam ruangan tertutup (green house) sederhana yang beratap plastik putih bergelombang dan berdinding GRC (Glassfibre Reinforced Cement). Ruangan tersebut tersinari matahari dan fluktuasi suhu tidak ekstrem.

\section{Penyiapan Sistem Pemeliharaan}

Bak fiber yang digunakan berukuran $2,1 \times 1,1 \times 0,45 \mathrm{~m}^{3}$ (Gambar 1$)$ yang diisi air setinggi $40 \mathrm{~cm}$. Dinding bak tidak rata, terdiri dari tiga bagian dengan ukuran berbeda dengan tinggi tiap bagian $15 \mathrm{~cm}$. Setiap bak diisi air sebanyak 875 L (Tabel 1).

\section{Pengaturan Kecepatan Arus}

Pembuatan arus air menggunakan pompa celup (submersible pump) yang dihubungkan dengan pipa paralon. Aliran air diatur dengan arah berlawanan dari kedua sisi lebar bak yang berbeda (arah memanjang). Cara ini menghasilkan arus yang relatif konstan dan merata (Gambar 1). 
Perbedaan kecepatan arus diatur dengan menggunakan pompa berkekuatan 5.000 L/jam dan $9.000 \mathrm{~L} /$ jam untuk memperoleh kecepatan arus $0,2 \mathrm{~m} / \mathrm{s}$ dan $0,4 \mathrm{~m} / \mathrm{s}$. Kecepatan arus diukur menggunakan current meter Flowatch FL-03 dengan lima kali pengulangan. Pemantauan kecepatan arus dilakukan secara periodik.

\section{Penyiapan Media Pemeliharaan}

Media pemeliharaan dipersiapkan dengan pemberian bioflok, molase, dan probiotik komersial EM4 ${ }^{\mathrm{TM}}$. Bioflok yang berasal dari kolam pemeliharaan ikan Patin Siam ditambahkan sebanyak $60 \mathrm{~L}$ pada awal penelitian ke dalam masing-masing bak percobaan. Molase ditambahkan sebanyak $10 \mathrm{~mL}$ setiap dua hari dan EM4 ${ }^{\mathrm{TM}}$ sebanyak $20 \mathrm{~mL}$ setiap pekan selama dua pekan. Setelah ikan dimasukkan, penambahan molase dan $\mathrm{EM} 4^{\mathrm{TM}}$ masingmasing sebanyak $10 \mathrm{~mL}$ dilakukan setiap pekan. Pemberian bioflok, molase, dan EM4 ${ }^{\mathrm{TM}}$ mengakibatkan air pemeliharaan menjadi keruh.

\section{Pelaksanaan Penelitian}

Penelitian dilakukan dengan tiga kali ulangan menggunakan tiga kecepatan arus, yaitu A (A1, A2, A3) 0 m/s sebagai kontrol, B (B1, B2, B3) 0,2 m/s, dan C (C1, C2, C3) $0,4 \mathrm{~m} / \mathrm{s}$. Pemenuhan kebutuhan oksigen pada perlakuan A menggunakan sistem aerasi dengan blower. Penelitian dilaksanakan selama 93 hari (November 2018-Februari 2019). Ikan Patin Pasupati diperoleh dari Balai Riset Pemuliaan Ikan, Kementerian Kelautan dan Perikanan (BRPI-KKP), Sukamandi.

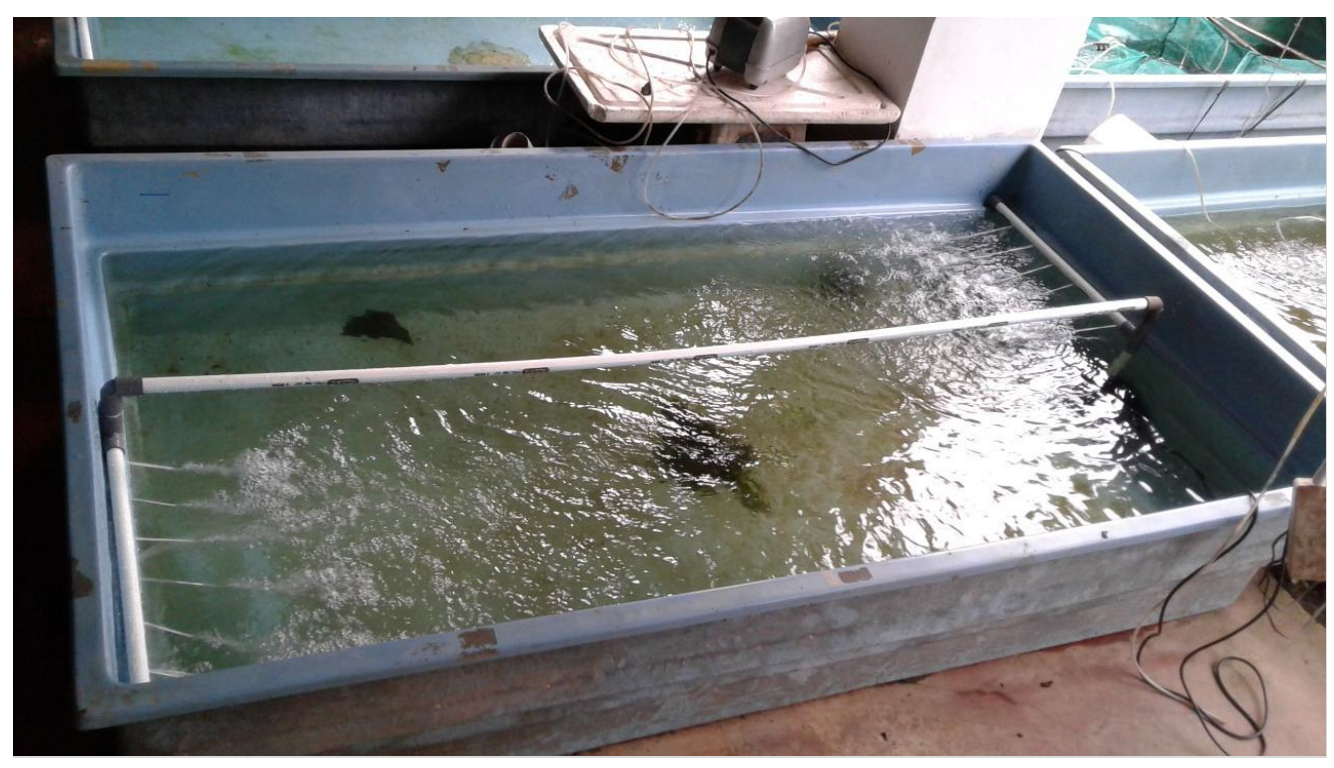

Gambar 1. Bak pemeliharaan dengan aliran arus berlawanan

Tabel 1. Ukuran bagian dalam bak pemeliharaan

\begin{tabular}{ccccc}
\hline Bagian bak & $\begin{array}{c}\text { Panjang } \\
(\mathrm{cm})\end{array}$ & $\begin{array}{c}\text { Lebar } \\
(\mathrm{cm})\end{array}$ & $\begin{array}{c}\text { Tinggi } \\
(\mathrm{cm})\end{array}$ & $\begin{array}{c}\text { Volume } \\
(\mathrm{L})\end{array}$ \\
\hline Bawah & 200 & 100 & 15 & 300,0 \\
Tengah & 206 & 108 & 15 & 333,7 \\
Atas & 210 & 115 & 10 & 241,5 \\
\hline \multicolumn{5}{c}{ Volume total } \\
\hline
\end{tabular}


Sebanyak 40 ekor ikan berukuran panjang 13,64 $\pm 1,26(12-14) \mathrm{cm}$ dan berat $24,41 \pm 3,87(22,07-29,19) \mathrm{g}$ dimasukkan ke dalam masing-masing bak pemeliharaan (kepadatan awal 1 ekor per $22 \mathrm{~L}$ air), dengan masa aklimatisasi selama delapan hari. Ukuran awal ikan diperoleh dari 20 ekor sampel ikan, dan digunakan sebagai ukuran awal untuk semua perlakuan.

\section{Penanganan Ikan selama Pengamatan}

Selama penelitian, ikan diberi pakan pelet apung merek Sinta dengan kadar protein minimal 30\%, lemak minimal 5\%, serat kasar maksimal 6\%, abu maksimal $12 \%$, dan kadar air maksimal 12\%. Pakan diberikan dua kali per hari (pagi dan petang). Pakan yang diberikan selama dua hari pertama berjumlah 3\% dari berat ikan. Jumlah tersebut kemudian ditambah secara bertahap hingga mencapai $5 \%$ dari berat ikan yang mulai diberikan pada hari kelima. Setelah penelitian berlangsung satu bulan, pakan diberikan secara ad libitum. Setelah masa pemeliharaan dua bulan, terlihat bahwa kemampuan ikan menghabiskan pakan menurun, sehingga jumlah pakan yang diberikan hanya 3\% dari biomassa total. Jumlah pakan yang diberikan untuk setiap bak dihitung untuk memperoleh nilai rasio konversi pakan (FCR).

Sebagai data pendukung, parameter kualitas air yang terdiri dari suhu, $\mathrm{pH}$, kandungan oksigen terlarut (DO), kekeruhan (turbiditas), amonia bebas, dan nitrit dipantau secara berkala. Suhu, $\mathrm{pH}$, DO, dan turbiditas diukur setiap minggu menggunakan Water Quality Checker (WQC) Horiba. Kandungan amonium dan nitrit dianalisis menggunakan metode spektrofotometri (APHA, 2017) pada awal penelitian $\left(\mathrm{T}_{0}\right)$ dan setiap pekan selama satu bulan pertama (November 2018). Pengamatan lanjutan dilakukan pada bulan Desember dan akhir penelitian (Februari 2019).

Data diolah dengan menggunakan Microsoft Excel 2010, dianalisis secara deskriptif dan dibandingkan dengan perlakuan kontrol. Komponen pengamatan dan penghitungannya pada ikan uji ditampilkan dalam Tabel 2.

\section{Hasil}

Hasil pemantauan kelangsungan hidup ikan selama masa aklimatisasi diperlihatkan dalam Tabel 3. Jumlah ikan di tiap bak pada awal penelitian $\left(\mathrm{T}_{0}\right)$ adalah jumlah ikan yang hidup sesudah aklimatisasi, maka berat total ikan di dalam setiap bak (Tabel 3 dan Tabel 4) menjadi dasar penghitungan jumlah pakan yang diberikan.

Hasil pengamatan berupa ukuran panjang dan berat akhir yang dicapai, pertambahan panjang dan berat, pertumbuhan spesifik harian panjang dan berat, pertumbuhan mutlak harian panjang dan berat, rasio konversi pakan (FCR), kelangsungan hidup (SR) ikan Patin Pasupati diperlihatkan dalam Tabel 5. Perlakuan C menunjukkan hasil tertinggi, kecuali nilai FCR.

Hasil pemantauan kualitas air ditunjukkan dalam Tabel 6. Suhu, pH, dan oksigen terlarut untuk ketiga perlakuan arus masih berada dalam kisaran kondisi optimum yang disyaratkan oleh SNI 7551:2009 mengenai pembesaran ikan Patin Pasupati. Kekeruhan tertinggi ditemukan pada perlakuan A, diikuti berturut-turut oleh perlakuan $\mathrm{B}$ dan $\mathrm{C}$. Kandungan amonia bebas dan nitrit lebih besar daripada kisaran nilai yang dipersyaratkan. Peningkatan kandungan amonia bebas terjadi pada hari ke-10 untuk semua perlakuan arus (Gambar 2). Pola yang serupa ditemukan pada kandungan nitrit, kecuali untuk perlakuan A yang menunjukkan peningkatan kandungan nitrit lebih lambat, yaitu pada hari ke-16. Puncak kandungan nitrit pada perlakuan A terjadi pada hari ke-24 (Gambar 2). Pada akhir penelitian, kandungan amonia bebas dan nitrit berada dalam kisaran yang dipersyaratkan SNI 7551:2009. 
Tabel 2. Komponen pengamatan pada ikan uji

\begin{tabular}{|c|c|}
\hline Komponen & Keterangan \\
\hline $\begin{array}{l}\text { Pertambahan panjang } \\
(\mathrm{cm})\end{array}$ & $\Delta \mathrm{L}=$ Panjang akhir $\left(\mathrm{T}_{\mathrm{a}}\right)-$ panjang awal $\left(\mathrm{T}_{0}\right)$ \\
\hline Pertambahan berat $(\mathrm{g})$ & $\Delta \mathrm{W}=$ Berat akhir $\left(\mathrm{T}_{\mathrm{a}}\right)-$ berat awal $\left(\mathrm{T}_{0}\right)$ \\
\hline $\begin{array}{l}\text { Pertumbuhan spesifik } \\
\text { panjang }(\%)\end{array}$ & SGR panjang $=\frac{\operatorname{Ln}(\text { panjang akhir })-\operatorname{Ln}(\text { panjang awal })}{\text { Jumlah hari pemeliharaan }} \times 100$ \\
\hline $\begin{array}{l}\text { Pertumbuhan spesifik } \\
\text { berat }(\%)\end{array}$ & SGR berat $=\frac{\operatorname{Ln}(\text { berat akhir })-\operatorname{Ln}(\text { berat awal })}{\text { Jumlah hari pemeliharaan }} \times 100$ \\
\hline $\begin{array}{l}\text { Pertumbuhan panjang } \\
\text { mutlak harian }(\mathrm{cm} / \text { hari })\end{array}$ & $\mathrm{Lm}=\frac{\text { Panjang akhir }\left(T_{a}\right)-\text { Panjang awal }\left(T_{0}\right)}{\text { Jumlah hari pemeliharaan }}$ \\
\hline $\begin{array}{l}\text { Pertumbuhan berat } \\
\text { mutlak harian }(\mathrm{g} / \mathrm{hari})\end{array}$ & $\mathrm{Wm}=\frac{\text { Berat akhir }\left(T_{a}\right)-\text { Berat awal }\left(T_{0}\right)}{\text { Jumlah hari pemeliharaan }}$ \\
\hline FCR & $\mathrm{FCR}=\frac{\text { Jumlah pakan yang dihabiskan }}{\text { Biomassa ikan yang dihasilkan }}$ \\
\hline Kelangsungan hidup (\%) & $\mathrm{SR}=\frac{\text { Jumlah ikan akhir }}{\text { Jumlah ikan awal }} \times 100$ \\
\hline
\end{tabular}

Tabel 3. Kelangsungan hidup ikan uji selama aklimatisasi

\begin{tabular}{ccccc}
\hline Bak & $\begin{array}{c}\text { Ikan awal } \\
\text { (ekor) }\end{array}$ & $\begin{array}{c}\text { Ikan mati } \\
\text { (ekor) }\end{array}$ & $\begin{array}{c}\text { Ikan hidup } \\
\text { (ekor) }^{*}\end{array}$ & $\begin{array}{c}\text { Kelangsungan } \\
\text { hidup }(\%)\end{array}$ \\
\hline A1 & 40 & 13 & 27 & 68 \\
A2 & 40 & 5 & 35 & 88 \\
A3 & 40 & 2 & 38 & 95 \\
B1 & 40 & 0 & 40 & 100 \\
B2 & 40 & 2 & 38 & 95 \\
B3 & 40 & 18 & 22 & 55 \\
C1 & 40 & 0 & 40 & 100 \\
C2 & 40 & 1 & 38 & 95 \\
C3 & 40 & 0 & 40 & 100 \\
\hline
\end{tabular}

${ }^{*}$ menjadi data $\mathrm{T}_{0}$ pada penelitian ini

Tabel 4. Jumlah dan berat total ikan pada awal penelitian $\left(\mathrm{T}_{0}\right)$

\begin{tabular}{cccccccccc}
\hline Bak & A1 & A2 & A3 & B1 & B2 & B3 & C1 & C2 & C3 \\
\hline Jumlah (ekor) & 27 & 35 & 38 & 40 & 38 & 22 & 40 & 38 & 40 \\
Berat total (g) & 659,07 & 854,35 & 927,58 & 976,40 & 927,58 & 537,02 & 976,40 & 927,58 & 976,40 \\
\hline
\end{tabular}


Tabel 5. Nilai parameter pertumbuhan dan kelangsungan hidup ikan Patin Pasupati

\begin{tabular}{|c|c|c|c|c|c|c|}
\hline \multirow{2}{*}{ Parameter } & \multicolumn{2}{|c|}{ A (kontrol) } & \multicolumn{2}{|c|}{$\mathrm{B}$ (Kecepatan arus $0,2 \mathrm{~m} / \mathrm{s})$} & \multicolumn{2}{|c|}{$\mathrm{C}$ (Kecepatan arus $0,4 \mathrm{~m} / \mathrm{s})$} \\
\hline & Rerata & Kisaran & Rerata & Kisaran & Rerata & Kisaran \\
\hline Panjang akhir $(\mathrm{cm})$ & $26,16 \pm 5,82$ & $20,14-31,75$ & $28,20 \pm 5,57$ & $22,10-33,00$ & $31,17 \pm 0,78$ & $30,40-31,95$ \\
\hline Berat akhir (g) & $192,72 \pm 132,16$ & $63,95-328,03$ & $270,49 \pm 105,64$ & $164,39-375,65$ & $295,72 \pm 43,02$ & $258,05-342,59$ \\
\hline Pertambahan panjang $(\mathrm{cm})$ & $12,52 \pm 5,82$ & $6,50-18,11$ & $14,56 \pm 5,57$ & $8,46-19,36$ & $17,53 \pm 0,78$ & $16,76-18,31$ \\
\hline Pertambahan berat (g) & $168,31 \pm 132,16$ & $39,54-303,62$ & $246,08 \pm 105,64$ & $139,98-351,24$ & $271,31 \pm 43,02$ & $233,64-318,18$ \\
\hline SGR panjang $(\%)$ & $0,68 \pm 0,25$ & $0,42-0,91$ & $0,77 \pm 0,22$ & $0,52-0,95$ & $0,89 \pm 0,03$ & $0,86-0,92$ \\
\hline SGR berat (\%) & $2,00 \pm 0,89$ & $1,04-2,79$ & $2,53 \pm 0,45$ & $2,05-2,94$ & $2,68 \pm 0,15$ & $2,54-2,84$ \\
\hline $\begin{array}{l}\text { Pertumbuhan panjang } \\
\text { mutlak harian }(\mathrm{cm} / \text { hari })\end{array}$ & $0,13 \pm 0,06$ & $0,07-0,20$ & $0,16 \pm 0,06$ & $0,09-0,21$ & $0,19 \pm 0,01$ & $0,18-0,20$ \\
\hline $\begin{array}{l}\text { Pertumbuhan berat mutlak } \\
\text { harian (g/hari) }\end{array}$ & $1,81 \pm 1,42$ & $0,43-3,27$ & $2,65 \pm 1,14$ & $1,51-3,78$ & $2,92 \pm 0,46$ & $2,51-3,42$ \\
\hline FCR & $1,43 \pm 0,40$ & $0,98-1,73$ & $1,48 \pm 0,28$ & $1,20-1,77$ & $1,45 \pm 0,30$ & $1,19-1,77$ \\
\hline $\mathrm{SR}(\%)$ & $72,10 \pm 45,16$ & $20,00-100,00$ & $64,49 \pm 27,87$ & $36,36-92,11$ & $87,98 \pm 10,84$ & $85,00-100,00$ \\
\hline
\end{tabular}


Tabel 6. Kualitas air pemeliharaan ikan Patin selama penelitian

\begin{tabular}{|c|c|c|c|}
\hline Parameter & Perlakuan & Kisaran & Acuan SNI 7551:2009 \\
\hline \multirow[t]{3}{*}{ Suhu $\left({ }^{\circ} \mathrm{C}\right)$} & $\mathrm{A}$ & $27,73-32,44$ & $27-31$ \\
\hline & B & $28,37-32,69$ & \\
\hline & $\mathrm{C}$ & $28,33-32,03$ & \\
\hline \multirow[t]{3}{*}{$\mathrm{pH}$} & A & $5,38-8,20$ & $6,5-8,5$ \\
\hline & B & $5,34-8,23$ & \\
\hline & $\mathrm{C}$ & $4,87-8,33$ & \\
\hline \multirow[t]{3}{*}{ DO (mg/L) } & A & $4,97-8,22$ & $\geq 3$ \\
\hline & B & $5,20-8,20$ & \\
\hline & $\mathrm{C}$ & $4,95-8,07$ & \\
\hline \multirow[t]{3}{*}{ Amonia (mg/L) } & A & $0,001-0,211$ & $<0,01$ \\
\hline & B & $0,001-0,140$ & \\
\hline & $\mathrm{C}$ & $0,001-0,205$ & \\
\hline \multirow[t]{3}{*}{ Nitrit (mg/L) } & A & $0,008-6,868$ & $<1$ \\
\hline & B & $0,006-8,629$ & \\
\hline & $\mathrm{C}$ & $0,004-5,859$ & \\
\hline \multirow[t]{3}{*}{ Kekeruhan (NTU) } & A & $135,00-347,67$ & - \\
\hline & B & $112,77-273,67$ & \\
\hline & $\mathrm{C}$ & $105,33-200,00$ & \\
\hline
\end{tabular}
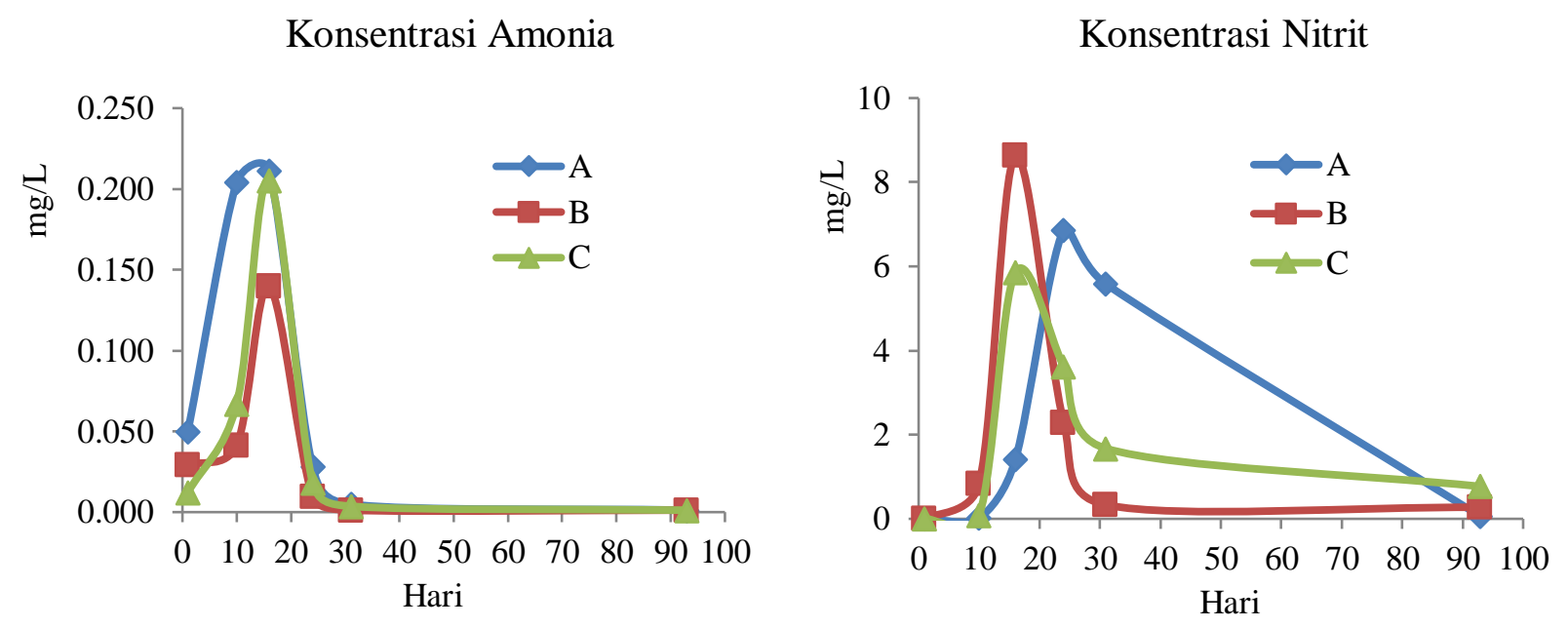

Gambar 2. Dinamika konsentrasi amonia dan nitrit selama penelitian

\section{Pembahasan}

Pada penelitian pendahuluan, ikan dipelihara menggunakan air PDAM, namun memberikan hasil yang kurang baik. Oleh sebab itu, penelitian ini dilaksanakan dengan menggunakan air PDAM yang diberi bioflok dan probiotik. Savitri et al. (2015) juga menggunakan bioflok dalam pemeliharaan ikan Patin Siam dan mendapatkan hasil 
terbaik dari perlakuan bioflok dengan tingkat pemberian pakan 5\%, FCR 1,24 dan SR 88\%. Pemeliharaan menggunakan bioflok pada budi daya ikan Lele Dumbo (Clarias gariepinus) berhasil memperbaiki nilai FCR dari 1,12 menjadi 0,96 dan meningkatkan kelangsungan hidup ikan dari 81,16 menjadi $95,70 \%$, serta memperbaiki kualitas air pemeliharaan. Selain itu, penggunaan bioflok dalam sistem pemeliharaan mampu mendukung kehidupan ikan Lele Dumbo hingga kepadatan 1.000 ekor/m² (Hastuti \& Subandiyono, 2014). Penggunaan probiotik pada pemeliharaan ikan Lele (Clarias sp.) dengan sistem akuaponik memberikan laju pertumbuhan dan kelangsungan hidup yang lebih tinggi dibandingkan sistem tanpa probiotik (Primashita et al., 2017). Penggunaan bioflok dan probiotik juga telah meningkatkan kelangsungan hidup, pertumbuhan, dan rasio konversi pakan udang Vanamae Litopenaeus vannamei (Dahlan et al., 2017). Sadi (2016) mengaplikasikan bioflok pada kolam pembesaran benih ikan Sidat Anguilla sp. dengan sistem beraliran dan nonaliran. Penerapan sistem aliran dalam kolam pemeliharaan ikan Sidat menghasilkan waktu aklimatisasi yang lebih singkat, kualitas air yang lebih baik, serta pertumbuhan dan kelangsungan hidup ikan yang lebih tinggi daripada nonaliran (Sadi, 2016).

Tabel 5 memperlihatkan bahwa perlakuan $\mathrm{C}$ memberikan hasil tertinggi pada komponen ukuran panjang dan berat akhir, pertambahan panjang, berat, pertumbuhan relatif harian, pertumbuhan mutlak, dan kelangsungan hidup ikan Patin Pasupati. Selain itu, kisaran ukuran yang dicapai juga relatif kecil atau pertumbuhan per individu relatif seragam. Berat akhir ikan pada perlakuan $\mathrm{C}$ adalah 295,72 \pm 43,02 g setelah tiga bulan pemeliharaan, yang hampir sama dengan hasil penelitian Nasa (2014) selama 2,5 bulan dalam kolam air deras yang mencapai ukuran $200 \mathrm{~g}$ dari kepadatan awal
$50 \mathrm{individu} / \mathrm{m}^{3}$ dan ukuran benih $20 \mathrm{~g}$. Hasil penelitian Sun et al. (2016) mendapatkan bahwa peningkatan laju aliran air pemeliharaan memberikan efek pada peningkatan laju pertumbuhan spesifik ikan Turbot (Scophthalmus maximus). Jobling et al. (1993) mendapatkan bahwa juvenil ikan Salmon yang dipelihara dalam air mengalir dengan arus yang setara dengan kecepatan berenang ikan pada kisaran 0,75-1,5 dari ukuran panjang badan per detik $\left(\mathrm{BL} \mathrm{s}^{-1}\right)$, tumbuh lebih cepat dan penggunaan pakan lebih efisien dibandingkan dengan juvenil ikan yang dipelihara dalam air diam. Jobling et al. (1993) juga menduga bahwa hal tersebut dikarenakan ada distribusi pakan yang lebih merata yang menyebabkan keseragaman tingkat pertumbuhan ikan dan kisaran ukuran yang rendah pada saat panen. Diduga pula keberadaan arus menyebabkan frekuensi interaksi agresif antara ikan menjadi rendah, sehingga tingkat kerusakan sirip lebih rendah dibandingkan dalam sistem pemeliharaan tanpa arus. Hal ini menunjukkan bahwa pemeliharaan dalam air berarus (mengalir) lebih baik daripada dalam air diam. Menurut Nasa (2014), budi daya ikan Patin lebih efektif jika dilakukan dalam kolam air deras. Budi daya air deras dapat dilakukan apabila debit air lebih dari $20 \mathrm{~L} / \mathrm{s}$. Belal (2015) mendapatkan bahwa kecepatan arus $35 \mathrm{~cm} / \mathrm{s}$ merupakan kecepatan arus optimum untuk pertumbuhan juvenil ikan Nila (Oreochromis niloticus) dan persentase filet ikan tertinggi dibandingkan kecepatan arus yang lebih rendah atau lebih tinggi. Solstorms et al. (2015) mendapatkan bahwa peningkatan kecepatan arus sampai ukuran kecepatan moderat $\left(0,8 \quad \mathrm{BL}^{-1}\right)$ telah meningkatkan kandungan protein ikan Salmon Atlantik (Salmo salar), sedangkan pada kecepatan arus rendah $\left(0,2 \mathrm{BL} \mathrm{s}^{-1}\right)$ menghasilkan ikan dengan kandungan lemak lebih tinggi. Waldrop et al. (2018) menyebutkan bahwa pergerakan renang ikan akibat arus yang lebih deras secara tidak 
langsung dapat meningkatkan kinerja pertumbuhan. Hal ini dikarenakan peningkatan arus air yang langsung melewati insang saat ikan berenang secara tidak langsung mengurangi kebutuhan ikan untuk melakukan ventilasi aktif lewat pemompaan oleh insang, sehingga proses pertukaran oksigen di insang berlangsung dengan energi yang lebih rendah dan energi yang berasal dari pakan dapat dimanfaatkan untuk pertumbuhan yang lebih baik.

Perlakuan C memberikan nilai kelangsungan hidup ikan tertinggi $(87,98 \pm$ $10,84 \%)$. Hasil ini hampir sama dengan hasil Tahapari dan Darmawan (2018) yang memperoleh kelangsungan hidup ikan Patin Pasupati sebesar $72,22-81,11 \%$ selama 6 bulan. Pada penelitian ini, mortalitas ikan diduga disebabkan oleh peningkatan kandungan amonia bebas dan nitrit yang terjadi pada awal pemeliharaan (Gambar 2). Toksisitas amonia bebas lebih tinggi daripada nitrit karena amonia bebas yang bersifat lipofilik lebih permeabel terhadap membran biologi (Mercante et al., 2018). Penelitian ini menunjukkan bahwa bioflok membutuhkan waktu dua hingga tiga minggu untuk dapat berperan secara optimal dalam menjaga kualitas air. Hal ini ditandai dengan penurunan kandungan amonia bebas dan nitrit pada minggu ke-3 masa pemeliharaan ikan (Gambar 2). Selanjutnya, kedua senyawa tersebut terus menurun hingga akhir penelitian. Kisaran konsentrasi amonia bebas yang diperoleh dari semua perlakuan lebih kecil daripada sistem konvensional sebagaimana yang diperoleh Abedin et al. (2017).

Toksisitas amonia bebas terutama disebabkan oleh reaksi penyempitan permukaan insang yang pada tahap lanjut akan menyebabkan penurunan kecepatan proses pertukaran gas dalam insang (Sutomo, 1989). Hasil studi Reichenbach-Klinke dalam Sutomo (1989) terhadap 240 jenis ikan air tawar mendapatkan bahwa konsentrasi
$\mathrm{NH}_{3}$ sebesar $0,27 \mathrm{mg} / \mathrm{L}$ atau lebih menyebabkan pembengkakan sel-sel insang dan hati, pelekatan filamen-filamen insang dan pertumbuhan yang berlebihan (hiperplasia) dengan diiringi oleh penurunan jumlah sel darah merah. Semua kondisi tersebut pada tahap lanjut dapat menyebabkan kematian ikan. Toksisitas nitrit disebabkan oleh kompetisi antara ion $\mathrm{NO}_{2}{ }^{-}$ dan ion $\mathrm{Cl}^{-}$dalam reaksi pertukaran pada sistem penukar ion $\left(\mathrm{HCO}_{3}{ }^{-} / \mathrm{Cl}^{-}\right)$pernafasan yang menghasilkan methaemoglobin dan nitrosilhaemoglobin (Hvas et al., 2016). Pembentukan kedua senyawa tersebut mengakibatkan kemampuan darah dalam mengikat oksigen menurun secara drastis. Dengan demikian, konsentrasi amonia bebas dan nitrit yang tinggi secara bersamaan akan menimbulkan kematian dengan cepat.

Penggunaan bioflok menyebabkan air pemeliharaan keruh dan berwarna gelap. Kekeruhan disebabkan oleh flok dari partikulat bahan organik dan konsorsium mikroorganisme dengan bakteri heterotrofik sebagai tulang punggung penyusunnya (de Schryver \& Verstraete, 2009). Nilai kekeruhan selama penelitian berkisar 105,33-347,67 NTU (Tabel 6). Aplikasi arus diduga menurunkan tingkat kekeruhan air karena arus yang semakin tinggi menghasilkan kekeruhan yang semakin rendah. Tingkat kekeruhan diduga berhubungan dengan bioturbasi yang terjadi akibat pergerakan ikan Patin yang merupakan ikan dasar. Peningkatan arus menyebabkan ikan Patin cenderung diam sebagai upaya mempertahankan posisi tubuh terhadap gaya dorong arus air. Akibatnya, bioturbasi yang terjadi menjadi lebih sedikit dan kekeruhan menjadi lebih rendah. Hal ini sejalan dengan hasil studi Taylor dan Cooke (2012) bahwa pada keadaan arus yang deras ikan menjadi kurang aktif bila kebutuhan energi untuk mencari makan terlalu tinggi. Simpson dan Mapleston (2002) dan Scruton et al. (2005) juga mendapatkan bahwa ikan cenderung 
tetap diam selama aliran sungai cukup deras bila terdapat perlindungan dalam bentuk daerah retensi hidrolik. Selain itu, kondisi gelap karena keberadaan bioflok diduga memengaruhi perilaku ikan Patin. Pemeliharaan larva ikan Patin $P$. hypophothalmus pada kondisi gelap dengan intensitas cahaya 0 dan 0,1 lux menghasilkan kelangsungan hidup, aktivitas berenang, kecepatan renang, konsumsi Artemia lebih tinggi, dan aktivitas menggigit rendah, sehingga menurunkan kanibalisme dibandingkan pemeliharaan dengan intensitas cahaya yang lebih terang, 1, 10, dan 100 lux (Foo, 2010).

Nilai FCR pada perlakuan A, B, dan C berturut-turut 1,43, 1,48, dan 1,45 (Tabel 5). Nilai ini menunjukkan bahwa perlakuan arus membutuhkan pakan yang lebih banyak daripada kontrol. Namun, peningkatan jumlah pakan tidak seiring dengan peningkatan arus. Nilai FCR ini lebih baik daripada FCR juvenil ikan Patin Nasutus yang bernilai 2,19 (Darmawan \& Tahapari, 2017). Husain et al. (2015) menyatakan bahwa perlakuan pemberian pakan tiga kali sehari menghasilkan FCR terbaik $(1,81)$ dan SGR 2,20\% pada benih ikan Patin $P$. hypophthalmus dalam 60 hari pemeliharaan. Barrows dan Hardy (2001) menyebutkan bahwa nilai FCR dapat dipengaruhi oleh beberapa faktor seperti berat tiap individu, kepadatan, umur, suhu air, dan pemberian pakan (kualitas, jumlah dan frekuensi pemberian pakan).

Persyaratan kualitas air untuk produksi ikan Patin Pasupati kelas pembesaran di kolam berdasarkan SNI 7551:2009 yaitu suhu berkisar $27-31^{\circ} \mathrm{C}$, pH 6,5-8,5, dan oksigen terlarut minimal $3 \mathrm{mg} / \mathrm{L}$. Suhu tertinggi sebesar $32,69^{\circ} \mathrm{C}$ (Tabel 6) dikarenakan tempat penelitian berupa ruangan tertutup dengan atap polikarbonat yang menyebabkan suhu air meningkat ketika cuaca sangat panas.

\section{Kesimpulan}

Kecepatan arus $0,4 \mathrm{~m} / \mathrm{s}$ menghasilkan pertambahan panjang dan berat, pertumbuhan relatif, pertumbuhan mutlak, dan kelangsungan hidup ikan Patin Pasupati tertinggi dalam penelitian ini. Kecepatan arus tidak berpengaruh pada nilai FCR yang relatif sama antara perlakuan dan peningkatan arus tidak diiringi dengan peningkatan jumlah pakan. Penelitian lanjutan diperlukan untuk memperoleh nilai kecepatan arus optimal yang menghasilkan pertumbuhan ikan Patin Pasupati yang maksimal.

\section{Ucapan Terima Kasih}

Penelitian ini dibiayai dari kegiatan INSINAS 2018 yang berjudul Kajian Kandungan Nutrisi Kolagen pada Ikan Patin (Pangasius sp,) sebagai Dasar Pengembangan Pangan Fungsional untuk Lansia. Terima kasih disampaikan kepada Bapak Sahroni, Bapak Heri, dan Bapak Ismail yang telah banyak membantu dalam pelaksanaan kegiatan penelitian.

\section{Referensi}

Abedin MJ, Bapary MAJ, Rasul MG, Majumdar BC, Haque MM. 2017. Water quality parameters of some Pangasius ponds at Trishal Upazila, Mymensingh, Bangladesh. European Journal of Biotechnology and Bioscience 5(2): 2935

Ahmad T, Rusmansyah, Sutrisno. 2008. Performansi calon induk Patin jambal (Pangasius djambal) pada volume bak dan cara aerasi berbeda. Jurnal Riset Akuakultur 3(1): 63-71

Andriyanto S, Listyanto N. 2011. Pertumbuhan dan kelangsungan hidup benih Patin jambal (Pangasius djambal) 
yang dipelihara dalam sistem resirkulasi dengan kepadatan berbeda. Prosiding Forum Inovasi Akuakultur: 131-136

APHA. 2017. Standard Methods for the Examination of Water and Wastewater. APHA: Washington DC

Barrow PA, Hardy. 2001. Probiotic for chickens. In: Probiotics the scientific basis. R. Filler (Ed). Chapman and Hall. London

Belal IEH. 2015. Effect of water velocity on Tilapia Oreochromis niloticus fingerlings growth parameters and body composition. Journal of Medical and Bioengineering 4(6): 457-460

Chai HJ, Li JH, Huang HN, Li TL, Chan YL, Shiau CY, Wu CJ. 2010. Effects of sizes and conformations of fish-scale collagen peptides on facial skin qualities and transdermal penetration efficiency. Journal of Biomedicine and Biotechnology: $\quad 1-9$ doi:10.1155/2010/757301

Cholik F, Jagatraya AG, Poernomo RP, Jauzi A. 2005. Akuakultur, Tumpuan Harapan Masa Depan Bangsa. Masyarakat Perikanan Nusantara dan Taman Akuarium Air Tawar TMII. Jakarta

Dahlan J, Hamzah M, Kurnia A. 2017. Pertumbuhan Udang Vaname (Litopenaeus vannamei) yang dikultur pada sistem bioflok dengan penambahan probiotik. Journal of Fishery Science and Innovation 1(1): 19-27

Darmawan J, Tahapari E. 2017. Performa pertumbuhan, koefisien variasi, dan heterosis hasil persilangan Ikan Patin (Pangasius sp.) pada tahap pendederan II. Jurnal Riset Akuakultur 12(1): 21-28 http://ejournal-

balitbang.kkp.go.id/index.php/jra

de Schryver P, Verstraete W. 2009. Nitrogen removal from aquaculture pond water by heterotrophic nitrogen assimilation in labscale sequencing batch reaktors. Bioresource Technology 100: 1162-1167
Diana JS, Fast AW. 1989. The effects of water exchange rate and density on yield of the walking catfish Clarias fuscus. Aquaculture 78(3-4): 267-276 https://doi.org/10.1016/00448486(89)90104-X

Friess W. 1998. Collagen-biomaterial for drug delivery. Review Article. European Journal of Pharmaceutics and Biopharmaceutics 45: 113-136 DOI: 10.1016/s0939-6411(98)00017-4

Foo NK. 2010. Feeding and swimming behavior of Patin Pangasius hypophthalmus larvae under dim light condition. Dissertation. Aquaculture Programme School of Science and Technology. University Malaysia Sabah

Hardyanti. 2014. Isolasi kolagen dari kulit ikan Patin (Pangasius sp.). Skripsi. Fakultas Kedokteran Hewan. Institut Pertanian Bogor

Hastuti S, Subandiyono. 2014. Performa produksi ikan lele dumbo (Clarias gariepinus Burch) yang dipelihara dengan teknologi bioflok. Jurnal Saintek Perikanan 10(1): 37-42

Huong LTT, Dzung NH, Tuan PD. 2014. Extraction and purification of collagen from the skins of Basa Fish (Pangasius hypophthalmus). Tap chi Khoa hgc va Cong nghe 52(4): 431-440

Husain MA, Hossain A, Mandal SC, Kabir MA, Rahman MS. 2015. Optimization of feeding frequency on the growth performance of thai pangas, Pangasius hypophthalmus (Sauvage, 1878). Dhaka University Journal of Biological Sciences 24(1): 83-90 DOI: 10.3329/dujbs.v24i1.46312

Hvas M, Damsgaard C, Gam LTH, Huong DTT, Jensen FB, Bayley M. 2016. The effect of environmental hypercapnia and size on nitrite toxicity in the striped catfish (Pangasianodon hypophthalmus). Aquatic Toxicology 176:151-60. DOI: 10.1016/j.aquatox.2016.04.020 
Jobling M, Baardvik BM, Christiansen JS, Jergensen EH. 1993. The effects of prolonged exercise training on growth performance and production parameter in fish. Aquaculture International 1(2): 95111 Tanggal diunduh 30 November 2017. https://link.springer.com/article/10.1007/ BF00692614

Kottelat M, Whitten AJ, Kartikasari SN, Wirjoatmodjo S. 1993. Ikan Air Tawar Indonesia Bagian Barat dan Sulawesi. Periplus Edition (HK) Ltd. Bekerjasama dengan Proyek EMDI. Kantor Menteri Negara Kependudukan dan Lingkungan Hidup Republik Indonesia. Jakarta

Mercante CTJ, David GS, Rodrigues CJ, do Carmo CF, da Silva RJ. 2018. Potential toxic effect of ammonia in reservoirs with Tilapia culture in cages. International Journal of Fisheries and Aquatic Studies 6(5): 256-261

Nasa DS. 2014. Budidaya Ikan Patin Pangasius djambal. Tanggal diunduh 6 April 2018. http://www.viternaplus.com/2014/09/budi daya-ikan-patin-pangasius-djambal.html

Primashita AH, Rahardja BS, Prayogo. 2017. Pengaruh pemberian probiotik berbeda dalam sistem akuaponik terhadap laju pertumbuhan dan survival rate Ikan Lele (Clarias sp.). Journal of Aquaculture Science 1(1): 1-9 DOI: https://doi.org/10.31093/joas.v1i1.1

Sadi NH. 2016. Inovasi teknologi budidaya dan pakan ikan sidat Anguilla sp. Laporan Akhir Kumulatif Kegiatan Unggulan LIPI Tahun 2016. Bogor. Pusat Penelitian Bioteknologi LIPI

Savitri A, Hasani Q, Tarsim. 2015. Pertumbuhan Ikan Patin Siam (Pangasianodon hypopthalmus) yang dipelihara dengan sistem bioflok pada feeding rate yang berbeda. e-Jurnal Rekayasa dan Teknologi Budidaya Perairan 4(1): 453-460. Tanggal diunduh 31

Oktober

2020. https://jurnal.fp.unila.ac.id/index.php/bdp i/article/view/1351/1242

Schram E, Verdegem MCJ, Widjaja RTOBH, Kloet CJ, Foss A, Schelvis-Smit R, Roth B, Imsland AK. 2009. Impact of increased flow rate on specific growth rate of juvenile turbot (Scophthalmus maximus, Rafinesque 1810). Aquaculture 292: 4652

Scruton DA, Pennell CJ, Robertson MJ, Ollerhead LMN, Clarke KD, Alfredsen K, Harby A, McKinley RS. 2005. Seasonal response of juvenile Atlantic salmon to experimental hydropeaking power generation in Newfoundland, Canada. North American Journal of Fisheries Management 25(3): 964-974 doi:10.1577/M04-133.1

Simpson R, Mapleston A. 2002. Movements and habitat use by the endangered Australian freshwater Mary River cod, Maccullochella peelii mariensis. Environ. Biol. Fishes 65(4): 401-410. doi:10.1023/A:1021129021451

Solstorms F, Solstorm D, Oppedal F, Ferno A, Fraser TWK, Olsen RE. 2015. Fast water currents reduce production performance of post-smolt Atlantic salmon Salmo salar. Aquaculture Environment Interactions 7: 125-134 DOI 10.3354/aei00143

SNI 7551: 2009. Produksi ikan patin pasupati (Pangasius sp.) kelas pembesaran di kolam

Sularto, Tahapari E, Hadie W. 2011. Identifikasi Karakter morfometrik sebagai penduga fekunditas Ikan Patin Jambal (Pangasius djambal) faktor kunci untuk seleksi. Jurnal Riset Akuakultur 6(1): 7-16

Sularto, Hadie W, Nurlaela I. 2012. Evaluasi performa pertumbuhan benih Ikan Patin jambal. Prosiding Indoaqua - Forum Inovasi Teknologi Akuakultur 2012, 10371044

Sularto, Darmawan J, Nurlaela I, Hadie W. 2014. Evaluasi pertumbuhan dan 
heritabilitas benih Patin jambal (Pangasius djambal) hasil silang balik F0 Betina dan Jantan F1 pada umur 18 dan 45 hari. Prosiding Forum Inovasi Akuakultur 2014, 771-779

Sun G, Li M, Wang J, Liu Y. 2016. Effects of flow rate on growth performance and welfare of juvenile turbot (Scophthalmus maximus L.) in recirculating aquaculture systems. Aquaculture Research 47(4): 1341-1352 doi:10.1111/are.12597

Supriyadi H, Taukhid, Effendi J. 2003. Identifikasi jasad penyebab penyakit pada benih Ikan Patin Jambal (Pangasius djambal) serta cara penanggulangannya. Jurnal Penelitian Perikanan Indonesia 9(4): 37-41

Suptijah P, Indriani D, Wardoyo SE. 2018. Isolasi dan karakterisasi kolagen dari kulit Ikan Patin (Pangasius sp.). Jurnal Sains Natural Universitas Nusa Bangsa 8(1): 823 http://doi.org./10,31398/jsn v8i1.106

Sutomo. 1989. Pengaruh amonia terhadap ikan dalam budidaya sistem tertutup. Oseana 14(1): 19-26

Tahapari E, Darmawan J, Dewi RSPS. 2017. Daya adaptasi tiga spesies Ikan Patin pada lingkungan yang berbeda. Jurnal Riset Akuakultur 12(3): 253-260

Tahapari E, Darmawan J. 2018. Kebutuhan protein pakan untuk performa optimal benih Ikan Patin Pasupati (Pangasiid). Jurnal Riset Akuakultur 13(1): 47-56 DOI: 10.15578/jra.13.1.2018.47-56.

Taylor MK, Cooke SJ. 2012. Meta-analyses of the effects of river flow on fish movement and activity. Environ. Rev. 20: 211-219. doi:10.1139/A2012-009

Vidthayanon C, Hogan Z. 2011. Pangasianodon hypophthalmus, The IUCN Red List of Threatened Species 2011: e,T180689A7649971, Tanggal $\begin{array}{llll}\text { diunduh } & 18 & \text { Januari } & 2019\end{array}$ http://dx.doi.org/10.2305/IUCN.UK.2011 - 1.RLTS.T180689A7649971.en.

Wagner EJ. 2015. A Review of the Effects of Flow on Brown Trout, Fisheries Experiment Station, Logan, UT 84321 November 2015. Tanggal diunduh 11 Januari 2019. https://wildlife.utah.gov/fes/pdf/revieweffects_of_flow_on_brown_trout_redds. pdf

Waldrop T, Summerfelt S, Mazik P, Good C. 2018. The effects of swimming exercise and dissolved oxygen on growth performance, fin condition and precocious maturation of early-rearing Atlantic Salmon Salmo salar. Aquaculture Research 49: 801-808. DOI: 10.1111/are.13511 